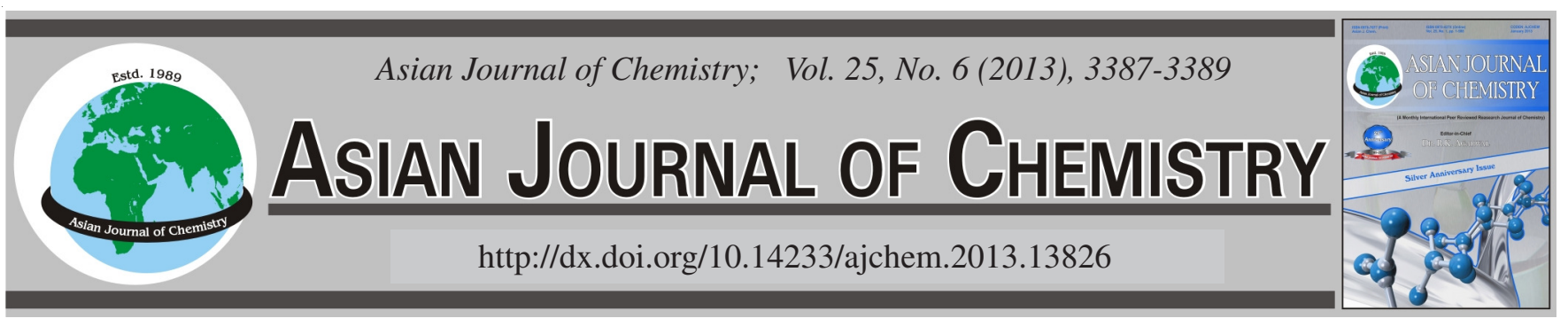

\title{
Synthesis and Supramolecular Structure of 3,3'-Dibromo-1,1'-[butane-1,4-diyldioxybis(nitrilomethylidyne)]dibenzene
}

Yin-Xia Sun ${ }^{*}$, Wei-Sheng Meng, Qing-Ying Lan, Xiao-Yan Zhang, Fei-Xia Ma and Da-Seng Wang

School of Chemical and Biological Engineering, Lanzhou Jiaotong University, Lanzhou 730070, P.R. China

*Corresponding author: E-mail: sun_yinxia@163.com

(Received: 3 April 2012;

Accepted: 21 December 2012)

AJC-12594

The compound, 3,3'-dibromo-1,1'-[butane-1,4-diyldioxybis(nitrilo-methylidyne)]dibenzene with the molecular formula $\mathrm{C}_{18} \mathrm{H}_{18} \mathrm{~N}_{2} \mathrm{O}_{2} \mathrm{Br}_{2}$,
was synthesized by the reaction of 3-bromobenzaldehyde with 1,4-bis(aminooxy) butane in ethanol. The molecule lies across a crystallographic
inversion centre (symmetry code: $-\mathrm{x},-\mathrm{y},-\mathrm{z}$ ) and adopts an extended form. Within the molecule, the two aromatic rings are aligned with the
angle of 5.57(3) $)^{\circ}$, but extend in opposite directions from the tetramethylene bridge. In the crystal structure, weak intermolecular $\mathrm{C}-\mathrm{H} \cdots \mathrm{O}$
hydrogen bonds and $\mathrm{C}-\mathrm{H} \cdots \pi$ stacking interactions link the title molecules into an infinite 3D supramolecular network structure.
Key Words: Bisoxime compound, Synthesis, Supramolecular structure.

\section{INTRODUCTION}

Salen-type compounds are one of most prevalent mixeddonor ligands in the field of coordination chemistry ${ }^{1-3}$. They play an important role in the development of coordination chemistry related to catalysis and enzymatic reactions, magnetism and supramolecular architectures. In the past few years, salen-type compounds have been used widely as ligands in the formation of transition metal complexes ${ }^{4,5}$. Many salentype complexes have been structurally characterized, but only a relatively small number of free salen-type bisoxime compounds have been characterized. As an extension of our work ${ }^{6-8}$, we report here the synthesis and crystal structure of a new salen-type bisoxime compound 3,3'-dibromo-1,1'-[butane-1,4diyldioxybis(nitrilomethylidyne)]dibenzene.

\section{EXPERIMENTAL}

3-Bromobenzaldehyde was purchased from Alfa Aesar and used without further purification. 1,4-Bis(aminooxy)butane was synthesized according to an analogous method reported earlier ${ }^{6}$. The other reagents and solvents were analytical grade reagents from Tianjin Chemical Reagent Factory. C, H and N analyses were carried out with a $\mathrm{GmbH}$ VariuoEL V3.00 automatic elemental analyzer. IR spectra in the range 4000-400 $\mathrm{cm}^{-1}$ were recorded on a VERTEX70 FT-IR spectrophotometer using $\mathrm{KBr}$ pellets. The ${ }^{1} \mathrm{H}$ NMR spectra were recorded on a Mercury-400BB spectrometer at room temperature using $\mathrm{CDCl}_{3}$ as solvent. X-Ray single crystal structure was determined on a Bruker Smart APEX CCD area detector. Melting points were measured by the use of a microscopic melting point apparatus made in Beijing Taike Instrument Limited Company and the thermometer was uncorrected.

General procedure: 3,3'-Dibromo-1,1'-[butane-1,4diyldioxybis(nitrilomethylidyne)]dibenzene was synthesized according to an analogous method reported earlier ${ }^{7,8}$. To an ethanolic solution ( $2 \mathrm{~mL}$ ) of 3-bromobenzaldehyde (407.7 mg, $2.13 \mathrm{mmol}$ ) was added an ethanolic solution $(3 \mathrm{~mL})$ of $1,4-$ bis(aminooxy)butane (128.1 mg, $1.07 \mathrm{mmol}$ ). The mixture solution was stirred at $328 \mathrm{~K}$ for $4 \mathrm{~h}$. When cooled to room temperature, the precipitate was filtered and washed successively with ethanol and ethanol-hexane (1:4), respectively. The product was dried under vacuum to yield $94.8 \mathrm{mg}$ of the title compound. Yield, $19.6 \%$. m.p. 323.5-325.5 K. Anal. calcd. (\%) for $\mathrm{C}_{18} \mathrm{H}_{18} \mathrm{~N}_{2} \mathrm{O}_{2} \mathrm{Br}_{2}$ : C, 47.60; H, 3.99; N, 6.17. Found (\%): C, 47.42; H, 3.83; N, 6.00. IR (KBr, $\left.\mathrm{v}_{\max }, \mathrm{cm}^{-1}\right): \mathrm{C}=\mathrm{N}, 1625$ and $\mathrm{C}-\mathrm{O}, 1176 .{ }^{1} \mathrm{H}$ NMR (400 $\left.\mathrm{MHz}, \mathrm{CDCl}_{3}\right): 2.05$ (t, $J=4.0$ $\left.\mathrm{Hz}, 4 \mathrm{H}, \mathrm{CH}_{2}\right), 4.22$ (t, $\left.J=4.0 \mathrm{~Hz}, 4 \mathrm{H}, \mathrm{CH}_{2}-\mathrm{O}\right), 6.86$ (d, J = 4.0 $\mathrm{Hz}, 2 \mathrm{H}, \mathrm{PhH}), 6.95$ (s, 2H, PhH), 7.22 (s, 2H, PhH), 7.36 (d, $J=4.0 \mathrm{~Hz}, 2 \mathrm{H}, \mathrm{PhH}), 8.03$ (s, 2H, N=CH). Colourless needleshaped single crystals suitable for X-ray diffraction studies were obtained after several weeks by slow evaporation from a methanol-acetonitrile mixed solution of 3,3'-dibromo-1,1' -[butane-1,4-diyldioxybis(nitrilomethylidyne)]dibenzene.

X-Ray structure determination: The single crystal of the title compound, with approximate dimensions of $0.48 \mathrm{~mm}$ $\times 0.38 \mathrm{~mm} \times 0.30 \mathrm{~mm}$ was placed on a Bruker Smart 1000 diffractmeter equipped with Apex CCD area detector. The diffraction data were collected using a graphite monochromated 
$\operatorname{MoK}_{\alpha}$ radition $(\gamma=0.71073 \AA$ ) at 298(2) K. The structure was solved by using the program SHELXS- $97^{9}$ and Fourier difference techniques and refined by full-matrix least-squares method on $\mathrm{F}^{2}$ using SHELXL- $97^{10}$. Details of the data collection and refinements of title compound are given in Table-1. The non-hydrogen atoms were refined anisotropically. Hydrogen atoms were added theoretically. CCDC: 696136.

\begin{tabular}{|c|c|}
\hline \multicolumn{2}{|c|}{$\begin{array}{l}\text { TABLE-1 } \\
\text { CRYSTAL DATA AND REFINEMENT PARAMETERS } \\
\text { FOR THE TITLE COMPOUND }\end{array}$} \\
\hline Empirical formula & $\mathrm{C}_{18} \mathrm{H}_{18} \mathrm{~N}_{2} \mathrm{O}_{2} \mathrm{Br}_{2}$ \\
\hline Formula weight & 454.16 \\
\hline Temperature & 298(2) K \\
\hline Wavelength & $0.71073 \AA$ \\
\hline Crystal system & Monoclinic \\
\hline Space group & $\mathrm{P} 2(1) / \mathrm{c}$ \\
\hline Cell dimensions & $\begin{array}{l}\mathrm{a}=11.9330(16) \AA, \mathrm{b}=4.8703(5) \\
\AA, \mathrm{c}=32.423(3) \AA \beta=99.706(2)\end{array}$ \\
\hline Volume & $1857.4(4) \AA^{3}$ \\
\hline $\mathrm{Z}$ & 4 \\
\hline Density (calculated) & $1.624 \mathrm{mg} / \mathrm{m}^{3}$ \\
\hline Absorption coefficient & $4.377 \mathrm{~mm}^{-1}$ \\
\hline$F_{(000)}$ & 904 \\
\hline Index ranges & $-14 \leq \mathrm{h} \leq 11,-5 \mathrm{k} \leq 5,-38 \leq 1 \leq 34$ \\
\hline Reflections collected & $8610 / 3256\left[\mathrm{R}_{\text {(int) }}=0.0505\right]$ \\
\hline Independent reflections & 3256 \\
\hline Data/restraints/parameters & $3256 / 0 / 217$ \\
\hline Goodness of fit indicator & 1.005 \\
\hline $\mathrm{R}[\mathrm{I}>2 \sigma(\mathrm{I})]$ & $\mathrm{R}_{1}=0.0766, \mathrm{wR}_{2}=0.1515$ \\
\hline Largest diff. peak and hole & 0.524 and -0.538 e. $\AA$ \\
\hline
\end{tabular}

\section{RESULTS AND DISCUSSION}

X-Ray crystallographic analysis revealed the crystal structure of title compound. And the structure is shown in Fig. 1. Selected bond distances and angles are listed in Table- 2 . The crystal structure of the title compound is built up by only the $\mathrm{C}_{18} \mathrm{H}_{18} \mathrm{~N}_{2} \mathrm{O}_{2} \mathrm{Br}_{2}$ molecules and all bond lengths and angles are in normal ranges ${ }^{6,7}$. The molecule assumes an extended

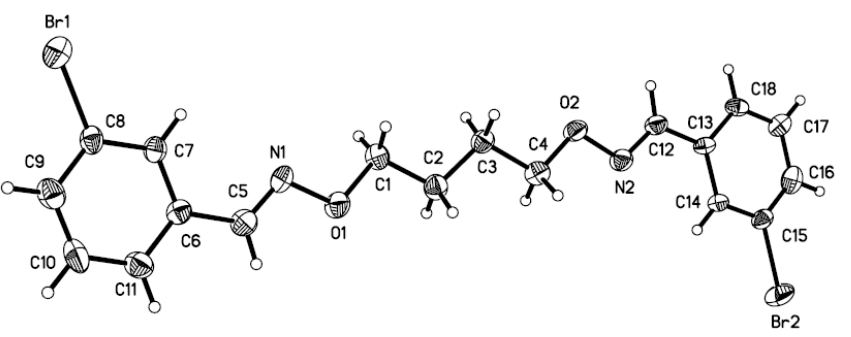

Fig. 1. Molecule structure of the title compound

conformation in which two benzaldoxime moieties are well separated from each other with a crystallographic inversion center (symmetry code: $-\mathrm{x},-\mathrm{y},-\mathrm{z}$ ). Within the molecule, the two aromatic rings are aligned with the angle of $5.57(3)^{\circ}$, but extend in opposite directions from the tetramethylene bridge.

In the crystal structure, $\mathrm{C}-\mathrm{H} \cdots \pi(\mathrm{Ph})$ stacking interactions and weak intermolecular $\mathrm{C}-\mathrm{H} \cdots \mathrm{O}$ hydrogen bonds link the neighboring molecules into an infinite three-dimensional supramolecular network structure. The title molecules are linked by a pair of intermolecular $\mathrm{C} 9-\mathrm{H} 9 \cdots \pi_{\text {centroid }(\mathrm{C} 13-\mathrm{C} 18)}$ hydrogen bond interactions into a $1 \mathrm{D}$ infinite zigzag chain along the c-axis. Furthermore, this linkage is further stabilized by a pair intermolecular C16-H16 $\cdots \pi_{\text {centroid (C6-C11) }}$ hydrogen bond interactions to form an infinite $2 \mathrm{D}$ crapy layer parallel to the bc-plane (Fig. 2). The intermolecular C-H $\cdots \pi_{\text {centroid }}$ separations are $c a .3 .214 \AA$ for $\mathrm{C} 16-\mathrm{H} 16 \cdots \pi_{\text {centroid (C6-C11) }}$ and $c a .3 .231 \AA$ for $\mathrm{C} 9-\mathrm{H} 9 \cdots \pi_{\text {centroid (C13-C18), }}$, respectively (Table-3) and lie in the accepted distance range for this type of contacts ${ }^{11}$. In addition, the adjacent crapy layers are further linked by the intermolecular $\mathrm{C} 18-\mathrm{H} 18 \cdots \mathrm{O} 2$ hydrogen bonds between the oxime oxygen atom and the methylene groups of the benzene ring. It is noteworthy that an infinite helices chain along the $b$-axis is formed by the $\mathrm{C} 18-\mathrm{H} 18 \cdots \mathrm{O} 2$ hydrogen bond interactions (Figs. 3 and 4). To sum up, with the help of intermolecular C-H... and $\mathrm{C}-\mathrm{H} \cdots \pi$ hydrogen-bonding interactions, the crystal packing shows a self-assembling 3D supramolecular network structure.

\begin{tabular}{|c|c|c|c|c|c|}
\hline \multicolumn{6}{|c|}{$\begin{array}{c}\text { TABLE-2 } \\
\text { SELECTED BOND LENGTHS }(\AA) \text { AND ANGLES }\left(^{\circ}\right) \text { FOR THE TITLE COMPOUND }\end{array}$} \\
\hline Bond & Lengths & Bond & Lengths & Bond & Lengths \\
\hline $\operatorname{Br}(1)-C(8)$ & $1.901(8)$ & $\mathrm{C}(9)-\mathrm{C}(10)$ & $1.368(12)$ & $\mathrm{O}(2)-\mathrm{C}(4)$ & $1.419(8)$ \\
\hline $\mathrm{N}(1)-\mathrm{C}(5)$ & $1.253(9)$ & $\mathrm{C}(12)-\mathrm{C}(13)$ & $1.480(10)$ & $\mathrm{C}(2)-\mathrm{C}(3)$ & $1.524(10)$ \\
\hline $\mathrm{N}(2)-\mathrm{C}(12)$ & $1.265(9)$ & $\mathrm{C}(13)-\mathrm{C}(18)$ & $1.413(9)$ & $C(5)-C(6)$ & $93(11)$ \\
\hline $\mathrm{O}(1)-\mathrm{C}(1)$ & $1.438(8)$ & $C(15)-C(16)$ & $1.387(11)$ & $C(6)-C(11)$ & $1.411(11)$ \\
\hline$C(1)-C(2)$ & $1.520(10)$ & $\mathrm{C}(17)-\mathrm{C}(18)$ & 1. $383(10)$ & $\mathrm{C}(8)-\mathrm{C}(9)$ & $1.380(11)$ \\
\hline $\mathrm{C}(3)-\mathrm{C}(4)$ & $1.510(9)$ & $\operatorname{Br}(2)-C(15)$ & $1.861(7)$ & $C(10)-C(11)$ & $1.342(11)$ \\
\hline$C(6)-C(7)$ & $1.376(10)$ & $\mathrm{N}(1)-\mathrm{O}(1)$ & $1.419(7)$ & $C(13)-C(14)$ & $1.372(9)$ \\
\hline $\mathrm{C}(7)-\mathrm{C}(8)$ & $1.387(10)$ & $\mathrm{N}(2)-\mathrm{O}(2)$ & $1.422(8)$ & $\mathrm{C}(14)-\mathrm{C}(15)$ & $1.386(10)$ \\
\hline $\mathrm{C}(16)-\mathrm{C}(17)$ & $1.376(11)$ & - & - & - & - \\
\hline $\mathrm{C}(5)-\mathrm{N}(1)-\mathrm{O}(1)$ & $108.6(7)$ & $\mathrm{C}(14)-\mathrm{C}(13)-\mathrm{C}(18)$ & $119.8(7)$ & $C(11)-C(6)-C(5)$ & $118.2(8)$ \\
\hline $\mathrm{N}(1)-\mathrm{O}(1)-\mathrm{C}(1)$ & $109.7(6)$ & $\mathrm{C}(18)-\mathrm{C}(13)-\mathrm{C}(12)$ & $118.0(7)$ & $\mathrm{C}(9)-\mathrm{C}(8)-\mathrm{C}(7)$ & $121.0(8)$ \\
\hline $\mathrm{O}(1)-\mathrm{C}(1)-\mathrm{C}(2)$ & $106.6(6)$ & $\mathrm{C}(14)-\mathrm{C}(15)-\mathrm{C}(16)$ & $118.9(8)$ & $\mathrm{C}(7)-\mathrm{C}(8)-\mathrm{Br}(1)$ & $119.4(6)$ \\
\hline$C(4)-C(3)-C(2)$ & $110.7(6)$ & $\mathrm{C}(16)-\mathrm{C}(15)-\mathrm{Br}(2)$ & $121.8(6)$ & $\mathrm{C}(11)-\mathrm{C}(10)-\mathrm{C}(9)$ & $123.5(9)$ \\
\hline $\mathrm{N}(1)-\mathrm{C}(5)-\mathrm{C}(6)$ & $122.2(8)$ & $C(16)-C(17)-C(18)$ & $119.0(8)$ & $\mathrm{N}(2)-\mathrm{C}(12)-\mathrm{C}(13)$ & $120.1(7)$ \\
\hline$C(7)-C(6)-C(5)$ & $121.0(7)$ & $\mathrm{C}(12)-\mathrm{N}(2)-\mathrm{O}(2)$ & $111.1(6)$ & $\mathrm{C}(14)-\mathrm{C}(13)-\mathrm{C}(12)$ & $122.2(7)$ \\
\hline$C(6)-C(7)-C(8)$ & $118.7(8)$ & $\mathrm{C}(4)-\mathrm{O}(2)-\mathrm{N}(2)$ & $108.3(5)$ & $\mathrm{C}(13)-\mathrm{C}(14)-\mathrm{C}(15)$ & $120.5(7)$ \\
\hline $\mathrm{C}(9)-\mathrm{C}(8)-\mathrm{Br}(1)$ & $119.6(6)$ & $\mathrm{C}(1)-\mathrm{C}(2)-\mathrm{C}(3)$ & $112.3(7)$ & $\mathrm{C}(14)-\mathrm{C}(15)-\mathrm{Br}(2)$ & $119.3(6)$ \\
\hline $\mathrm{C}(10)-\mathrm{C}(9)-\mathrm{C}(8)$ & $118.0(8)$ & $\mathrm{O}(2)-\mathrm{C}(4)-\mathrm{C}(3)$ & $108.4(6)$ & $\mathrm{C}(17)-\mathrm{C}(16)-\mathrm{C}(15$ & $121.9(8)$ \\
\hline$C(10)-(11)-C(6)$ & $117.7(9)$ & $C(7)-C(6)-C(11)$ & $120.8(7)$ & $\mathrm{C}(17)-\mathrm{C}(18)-\mathrm{C}(13)$ & $119.9(7)$ \\
\hline
\end{tabular}




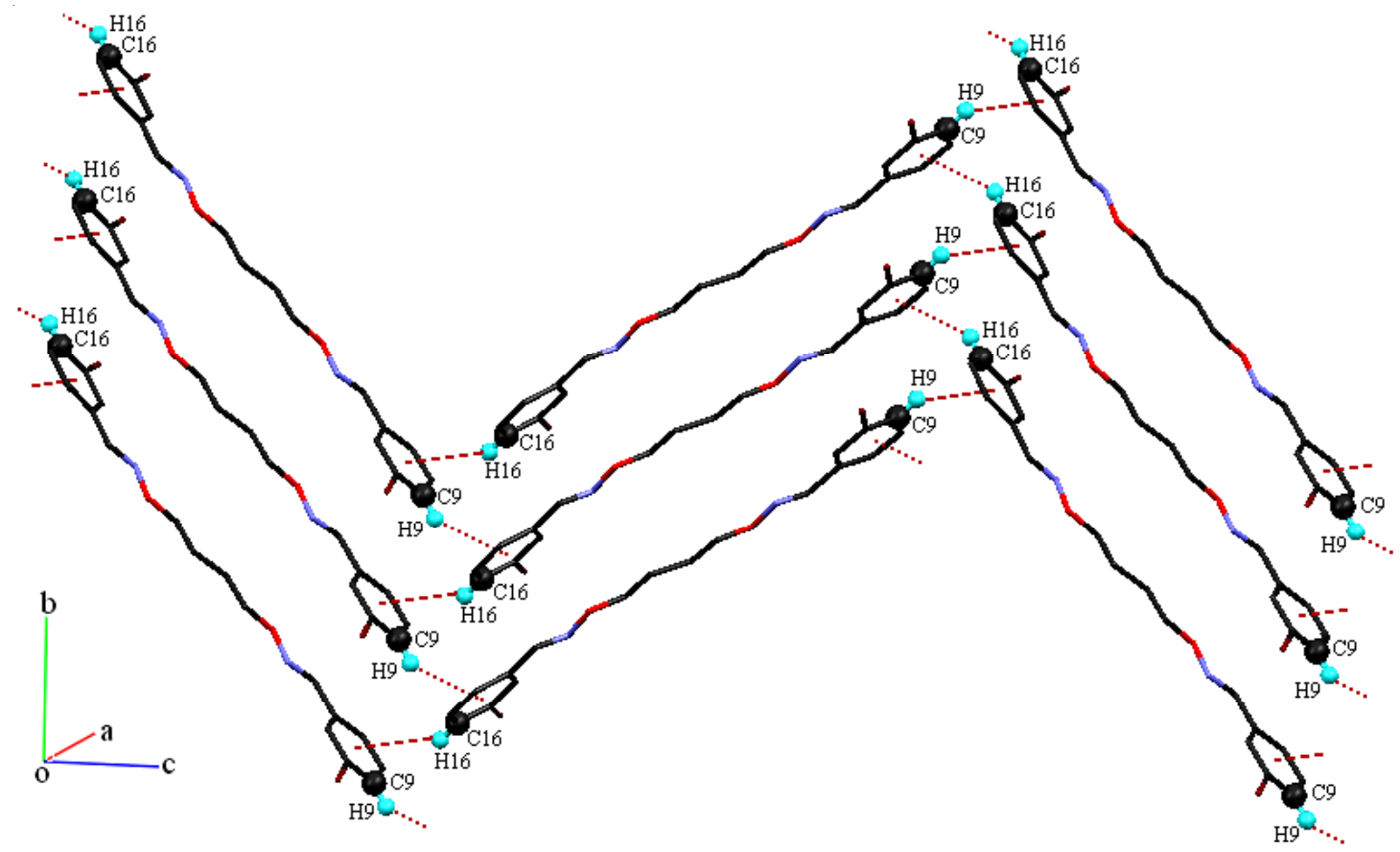

Fig. 2. View of the 1D supramolecular zigzag chain and 2D crapy layers within the title compound (hydrogen atoms, except those forming hydrogen bonds, are omitted for clarity)

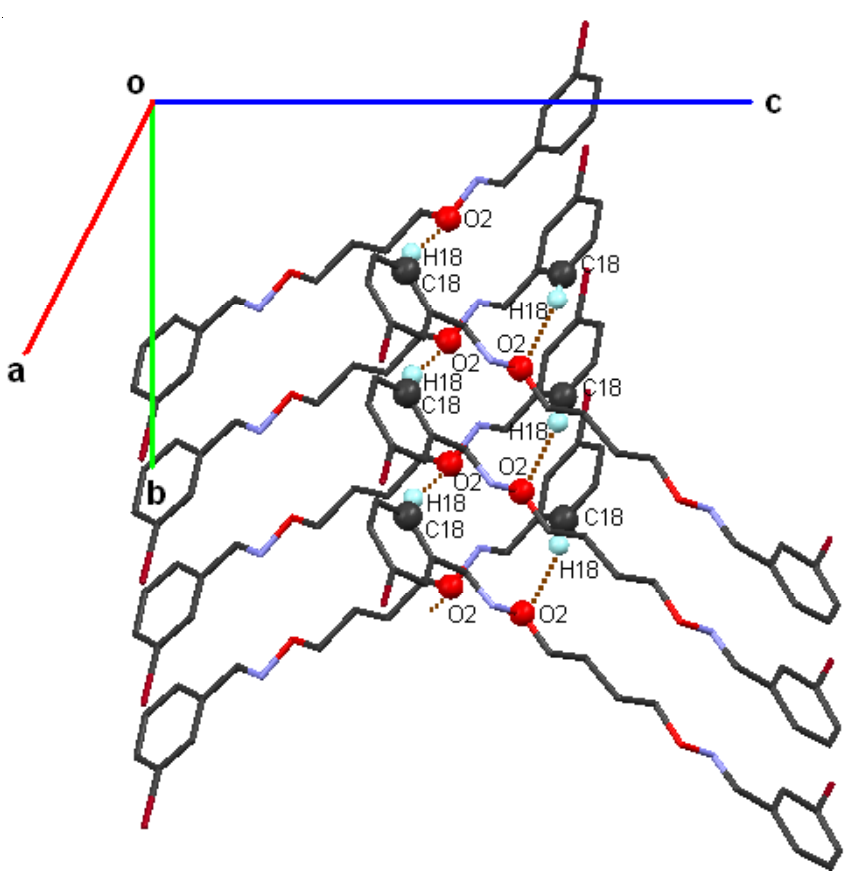

Fig. 3. Intermolecular $\mathrm{C} 18-\mathrm{H} 18 \cdots \mathrm{O} 2$ hydrogen bonds. For clarity, the $\mathrm{H}$ atoms not involved in the interactions have been omitted

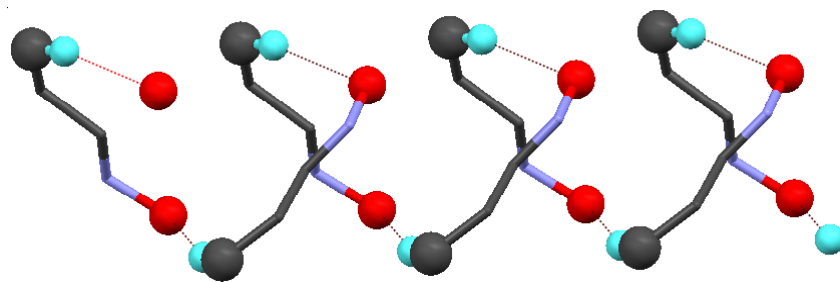

Fig. 4. Helix chain linked by $\mathrm{C} 18-\mathrm{H} 18 \cdots \mathrm{O} 2$ hydrogen bonds. For clarity, the non-contact atoms not involved in the interactions have been omitted

\begin{tabular}{|c|c|c|c|c|}
\hline \multicolumn{5}{|c|}{$\begin{array}{c}\text { TABLE-3 } \\
\text { HYDROGEN-BONDING DATA }\left[\AA{ }^{\circ}\right]\end{array}$} \\
\hline D-H $\cdots A$ & $\mathrm{~d}(\mathrm{D}-\mathrm{H})$ & $\mathrm{d}(\mathrm{H} \cdots \mathrm{A})$ & $\mathrm{d}(\mathrm{D} \cdots \mathrm{A})$ & $\angle \mathrm{D}-\mathrm{H} \cdots \mathrm{A}$ \\
\hline $\mathrm{C} 18-\mathrm{H} 18 \cdots \mathrm{O} 2$ & 0.93 & 2.51 & $3.417(3)$ & 161 \\
\hline $\mathrm{C} 16-\mathrm{H} 16 \cdots \mathrm{Cg} 1^{\mathrm{a}}$ & 0.93 & 3.21 & $4.012(4)$ & 146 \\
\hline $\mathrm{C} 9-\mathrm{H} 9 \cdots \mathrm{Cg} 2^{b}$ & 0.93 & 3.23 & $4.008(4)$ & 143 \\
\hline
\end{tabular}

${ }^{\mathrm{a}} \mathrm{Cg} 1$ is the $\mathrm{C} 6-\mathrm{C} 11$ ring centroids. ${ }^{\mathrm{b}} \mathrm{Cg} 2$ is the $\mathrm{C} 13-\mathrm{C} 18$ ring centroid.

\section{ACKNOWLEDGEMENTS}

The authors thank Young Scholars Science Foundation of Lanzhou Jiaotong University (2011007) for financial support of this work.

\section{REFERENCES}

1. B. Sieklucka, R. Podgajny, P. Przychodzen and T. Korzeniak, Coord. Chem. Rev., 249, 2203 (2005).

2. J.D. Dyers, S.Y. Que, D. VanDerveer and X.R. Bu, Inorg. Chim. Acta, 359, 197 (2006).

3. R. Klement, F. Stock, H. Elias, H. Paulus, P. Pelikan, P. Valko and M. Mazur, Polyhedron, 18, 3617 (1999).

4. S. Akine, W.K. Dong and T. Nabeshima, Inorg. Chem., 45, 4677 (2006).

5. W.K. Dong, J.H. Feng and X.Q. Yang. Synth. React. Inorg. Met.-Org. Nano-Met. Chem., 37, 189 (2007).

6. W.K. Dong, J.H. Feng, L. Wang, L. Xu, L. Zhao and X.Q. Yang, Transition Met. Chem., 32, 1101 (2007).

7. W.K. Dong, J.G. Duan and G.L. Liu, Transition Met. Chem., 32, 702 (2007).

8. W.K. Dong, J.Y. Shi, J.K. Zhong, Y.Q. Tian and J.G. Duan, Chin. J. Inorg. Chem., 24, 10 (2008).

9. G.M. Sheldrick, SHELXS97, Program for Crystal Structure Determination, University of Göttingen, Germany (1996).

10. G.M. Sheldrick, Acta Cryst., A64, 112 (2008).

11. J. Lewin Ski, J. Zachara, I. Justyniak and M. Dranka, Coord. Chem. Rev., 249, 1185 (2005). 